\title{
Experimental Investigation on Steel Fibre Reinforced Fly Ash (Class-C) Based Alkali Activated Geo-Polymer Concrete
}

\author{
Abida Justus* R.Padmapriya \\ Department of Civil Engineering,Sathyabama Institute of Science and technology, Chennai-600 119, India
}

\begin{abstract}
Geo-polymer concrete (GPC) are representing the most promising green and eco-friendly alternative to Ordinary Portland cement (OPC). This paper presents the results of an experimental program on the mechanical properties of steel fibres reinforced geo-polymer concrete (SFRGPC) such as Compressive strength, Split tensile strength, Flexural strength, Water absorption, Alkali attack, Acid attack and Abrasion resistance. SFRPGPC contains Fly ash (Class- C), alkaline liquids, fine aggregate, coarse aggregate and steel fibres. Alkaline liquid to fly ash ratio was fixed as 0.45 with $100 \%$ replacement of OPC. For alkaline liquid combination ratio of sodium silicate to sodium hydroxide solution was fixed as 2.5 . Steel fibres was added to the mix in volume fractions of $0 \%, 0.25 \%$, and $0.5 \%$ by volume of geo-polymer concrete. Specimens were subjected to air curing at room temperature. Based on the test results Compressive strength, Split tensile strength and Flexural strength showed maximum values for $0.5 \%$ dosage of steel fibre. Hence, it is concluded that the addition of $0.5 \%$ steel fibres dosage increase the strength of geo-polymer concrete which is due to the hooked end shape of steel fibres, which provide better adhesion between fibre and concrete and can be used in the marine environment.
\end{abstract}

Keywords: fly ash (Class C), steel fibre, flexural strength, compressive strength, split tensile test

DOI: $10.7176 / \mathrm{CER} / 11-3-03$

Publication date: April $30^{\text {th }} 2019$

\section{Introduction}

In order to make construction industry greener/eco-friendly, there is a need to develop an alternate binding material which is comparable or even superior to cement. There is a demand to develop more eco-friendly new technology that utilizes new bonding materials to replace Ordinary Portland cement (OPC). Many Lignite industries produce huge amount of post process waste which are dumped in the environment, which leads to serious problems related to pollution of soil and water. This can be solved by using this waste for the production of new, eco-friendly materials. One such development is the production of geo-polymer concrete using Class $-\mathrm{C}$ fly ash from NLC Neyveli as the base for construction material. This reduces energy consumption in the manufacturing process.

The findings of this study (Faiz et al, 2013), showed that the mechanical properties of short fibre reinforced geopolymer composites. Geo-polymer concrete exhibits brittle behaviour due to its low tensile strength. Addition of fibres changes its brittleness to ductility with significant improvement in tensile strength, tensile strain, toughness and energy absorption capacities. The findings of this study (Mark et.al, 2014) showed that the properties of fibre reinforced geo-polymer concrete with ambient curing for in-situ applications. It was evident from the results that the addition of polypropylene fibres enhanced the compressive strength and the ductility of geo-polymer concrete. The findings of this study (Lembo et.al,2014), showed that the structural performance of geo-polymer concrete with FRP confinement and concluded that the ductility of geo-polymer concrete can be increased by fibre reinforced polymer (FRP) confinement. The findings of this study (Motohiro et al, 2014) showed that the feasibility of strain hardening fibre reinforced fly ash based geo-polymer composites. Crack width distributions were investigated by the Digital Image Correlation technique. The analysis indicated that the maximum and average crack widths are $117 \mu \mathrm{m}$ and $45 \mu \mathrm{m}$, respectively, even at a high imposed strain level of $4.5 \%$. Therefore, the feasibility of strain-hardening ductile geo-polymer composites was established. The findings of this study (Kinga Korniejenko et.al, 2015), showed that the properties of fly ash based fibre-reinforced geo-polymer composites as an environmental friendly alternative to cementitious materials. Results show that the appropriate addition of polypropylene fibres can improve the mechanical properties of geo-polymer composites.

\section{Materials and methods}

The materials used are Fly ash (Class-C), Fine aggregates, Coarse aggregate, Steel fibre and Alkaline solutions $\left(\mathrm{NaOH}\right.$ and $\left.\mathrm{Na}_{2} \mathrm{SiO}_{3}\right)$.

2.1 Fly ash (Class-C)The low calcium fly ash (class C) collected from Neyveli Lignite Corporation Limited, Tamil $\mathrm{Nadu}$, India, was used as the source material for the preparation of geo-polymer concrete.The specific gravity of fly ash is 2.52 . (Table 1) shows the properties of fly ash. 
Table 1 Properties of Fly Ash Class - C

\begin{tabular}{|l|c|}
\hline \multicolumn{1}{|c|}{ Properties } & Fly Ash Class C \\
\hline Silicon dioxide $\left(\mathrm{SiO}_{2}\right)$, aluminium oxide $\left(\mathrm{Al}_{2} \mathrm{O}_{3}\right)$ and iron oxide $\left(\mathrm{Fe}_{2} \mathrm{O}_{3}\right)$, min, \% & 50.0 \\
\hline Sulphur trioxide $\left(\mathrm{SO}_{3}\right)$, max, \% & 5.0 \\
\hline Moisture Content, max, \% & 3.0 \\
\hline Loss on ignition, max, \% & 6.0 \\
\hline
\end{tabular}

2.2 Fine aggregate: Fine aggregate is defined as those materials that passes through $4.75 \mathrm{~mm}$ sieve and will for the most part, be retained on a $75 \mu$ sieve. In this work, India river sand is used as fine aggregate. The sand was washed and screened at site to remove deleterious materials.

2.3 Coarse aggregate: Coarse aggregate consists of river gravel, crushed stone or manufacturing aggregate with particle size equal to or greater than $4.75 \mathrm{~mm}$. In this research coarse aggregates of maximum size $10-12 \mathrm{~mm}$ were used and the specific gravity is 2.71 .

2.4 Steel Fibre: Hooked end steel fibres were added to geo-polymer concrete to increase the crack resistance, flexibility, ductility and toughness of the concrete. It results in high tensile strength, improves load bearing capacity etc., The ending shapes of the fibre ie., hooked end steel fibre are very important to grant adhesion between fibre and concrete. The length and diameter of steel fibres used is $30 \mathrm{~mm}$ and $0.60 \mathrm{~mm}$. The aspect ratio is 50 .

2.5 Alkaline solution: Sodium hydroxide solution mixed with Sodium silicate solution was used as an alkaline activator for geo-polymerization. The commercially available sodium hydroxide in the form of flakes was used in this study. Sodium silicate is in liquid form.

2.6 X-ray diffraction: X-Ray Diffraction (XRD) qualitatively identifies the crystalline phases of the fly ash sample. Electrons hit a solid sample and X-rays are emitted. When the x-rays hit a crystal structure, some x-rays diffract based on this crystal structure but other x-rays penetrate further into the sample until colliding into a crystal. The machine reads all of the angles of diffracted, scattered $x$-rays and their intensities to create a pattern. These patterns are plotted, creating a diffractogram, relating diffracted intensity to diffraction angle. The X-Ray Diffraction for Fly ash Class-C is represented in the form of graph in( Figure1)

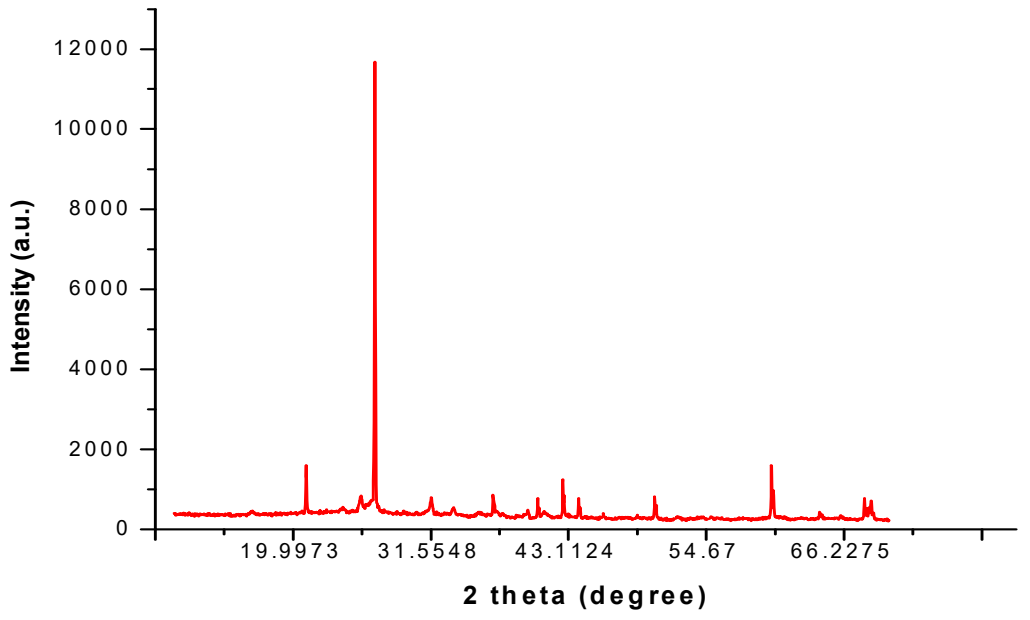

Figure 1 X-Ray Diffraction pattern for Class-C

$\mathrm{X}$-Ray Diffraction studies were carried out for C-Class fly ash and the pattern confirms the presence of $\mathrm{Al}_{2} \mathrm{O}_{3}$ and $\mathrm{SiO}_{2}$ as predominant materials. The XRD pattern for C-Class fly ash illustrates that the main crystalline phases are quartz (JCPDS No. 89 - 1668) and mullite (JCPDS No. 88 - 0107) and the other crystalline phases present are hematite $\left(\mathrm{Fe}_{2} \mathrm{O}_{3}\right)$ and calcium oxide $(\mathrm{CaO})$. These patterns were matched with (JCPDS No. 89 - 7746) and (JCPDS No. 82 - 1690) respectively. These patterns were similar to the C-Class fly ash values recorded earlier. Very high intensity of calcium oxide in XRD pattern validates significant presence of calcium in C-Class fly ash. According to ACI (American Concrete Institute), the presence of quartz, hematite and calcium oxide increases strength and improves the durability of concrete. 


\section{Mix proportions}

The following (Table 2) shows the mix proportions of geo-polymer concrete using fly ash (class-c) for one paver block.

Table 2 Mix proportions for one paver block

\begin{tabular}{|c|c|c|c|c|c|c|}
\hline Mix & $\begin{array}{c}\text { Fly ash } \\
{[\mathbf{k g}]}\end{array}$ & $\begin{array}{c}\mathbf{N a O H} \\
{[\mathbf{k g}]}\end{array}$ & $\begin{array}{c}\mathbf{N a}_{2} S_{0} \\
{[\mathbf{k g}]}\end{array}$ & $\begin{array}{c}\text { Fine } \\
\text { aggregate }[\mathbf{k g}]\end{array}$ & $\begin{array}{c}\text { Coarse } \\
\text { aggregate }[\mathrm{kg}]\end{array}$ & $\begin{array}{c}\text { Water } \\
{[\mathbf{k g}]}\end{array}$ \\
\hline $\begin{array}{c}\text { M1 } \\
\left(\begin{array}{c}0 \% \text { Steel } \\
\text { Fibre })\end{array}\right.\end{array}$ & 1.212 & $\begin{array}{c}0.122 \\
(8 \mathrm{M})\end{array}$ & 0.307 & 1.65 & 3.868 & 0.67 \\
\hline $\begin{array}{c}\text { M2 } \\
(0.25 \% \text { Steel } \\
\text { Fibre })\end{array}$ & 1.212 & $\begin{array}{c}0.122 \\
(8 \mathrm{M})\end{array}$ & 0.307 & 1.65 & 3.868 & 0.67 \\
\hline $\begin{array}{c}\text { M3 } \\
(0.50 \% \text { Steel } \\
\text { Fibre })\end{array}$ & 1.212 & $\begin{array}{c}0.122 \\
(8 \mathrm{M})\end{array}$ & 0.307 & 1.65 & 3.868 & 0.67 \\
\hline
\end{tabular}

3.1 Specimen details: Totally 96 blocks were casted and cured in room temperature for testing. The moulds were divided into three groups, M-1, M-2, and M-3 based on the dosage of steel fibres. Each mix consists of 32 moulds with different dosage of steel fibres. The paver block is in hexagonal shape of side $120 \mathrm{~mm}$, area $37440 \mathrm{~mm}^{2}$, and thickness $80 \mathrm{~mm}$.In addition to this, 2 cubes of each mix measuring $7 \mathrm{~cm} \mathrm{x} 7 \mathrm{~cm} \mathrm{x} 7 \mathrm{~cm}$, are casted for abrasion test.

Measurements of one paver block:

Length $(\mathrm{L} / \mathrm{a})=120 \mathrm{~mm}$

Height $(\mathrm{h})=80 \mathrm{~mm}$

Volume $(\mathrm{v})=0.00299 \mathrm{~m}^{3}$

Area $(\mathrm{A})=37440 \mathrm{~mm}^{2}$

3.2 Preparation of alkaline solution: The weighed quantity $(480 \mathrm{~g})$ of Sodium Hydroxide $(\mathrm{NaOH})$ in the form of flakes to suit 8 Molarity $(8 \mathrm{M})$ is allowed to dissolve in distilled water and made up to one litre. By trial and error, 300 gms of $\mathrm{NaOH}$ solution can be obtained when $120 \mathrm{gms}$ of $\mathrm{NaOH}$ flakes are mixed in a makeup jar of $250 \mathrm{ml}$. 3.3 Casting the specimen: First, the dry materials used for preparing geo-polymer concrete were mixed. Then alkaline solution and the required extra water were mixed. Machine oil was tarnished and the freshly mixed geopolymer concrete was placed into the paver mould. Each mould was then vibrated for 15 seconds using a mechanical vibrator. After the top surface was leveled the moulds were left at room temperature for ambient curing.(Figure 2) shows the casted specimens. (Table 3) shows the number of specimen cast.

Table 3 Number of specimen casted for specified test

\begin{tabular}{|l|c|c|c|}
\hline \multicolumn{1}{|c|}{ Name of the test } & Mix 1 & Mix 2 & Mix 3 \\
\hline Compression strength & 12 & 12 & 12 \\
\hline Split tensile strength & 6 & 6 & 6 \\
\hline Flexural strength & 6 & 6 & 6 \\
\hline Acid attack (Sulphuric acid 5\%) & 2 & 2 & 2 \\
\hline Alkali attack (Sodium hydroxide 4\%) & 2 & 2 & 2 \\
\hline Water absorption & 3 & 3 & 3 \\
\hline Abrasion (7 cm X 7cm X 7cm cube) & 2 & 2 & 2 \\
\hline Total number of blocks casted & 32 & 32 & 32 \\
\hline
\end{tabular}




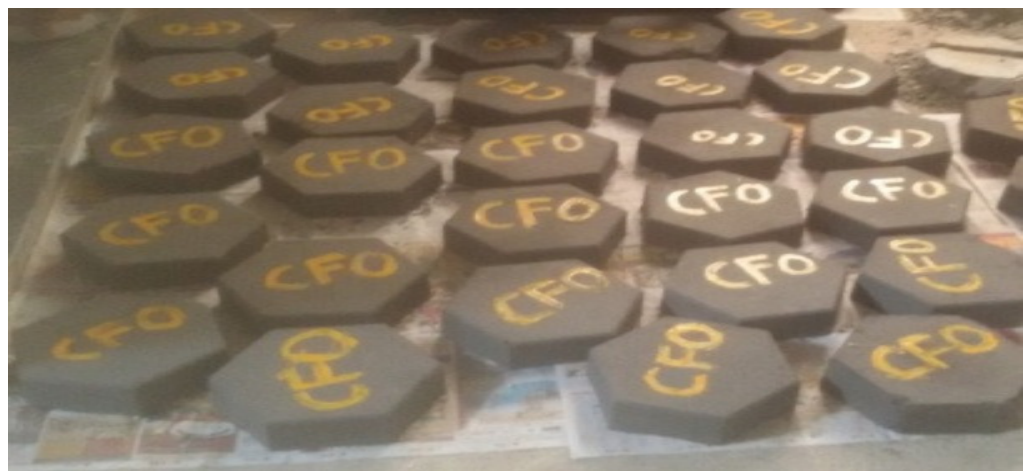

Figure 3 Casted specimen

\section{Testing of specimens}

As per the IS 15658:2006 the following tests were performed to determine its strength.

4.1 Compressive strength test: For each mix proportions, nine paver blocks were tested, using compression testing machine of $3000 \mathrm{kN}$ capacity as per IS 15658:2006 code.

4.2 Split tensile strength test: The test was carried out along the longest splitting section of the specimen, parallel and symmetrical to the edges, in such a way that the distance of the splitting section to any side face was at least 0.5 times the thickness of the specimen over at least 75 percent of splitting section area. Since the section of the specimen is hexagonal in plan, the splitting section was chosen in such a way that it was the shortest length passing through the centre of the plan area.
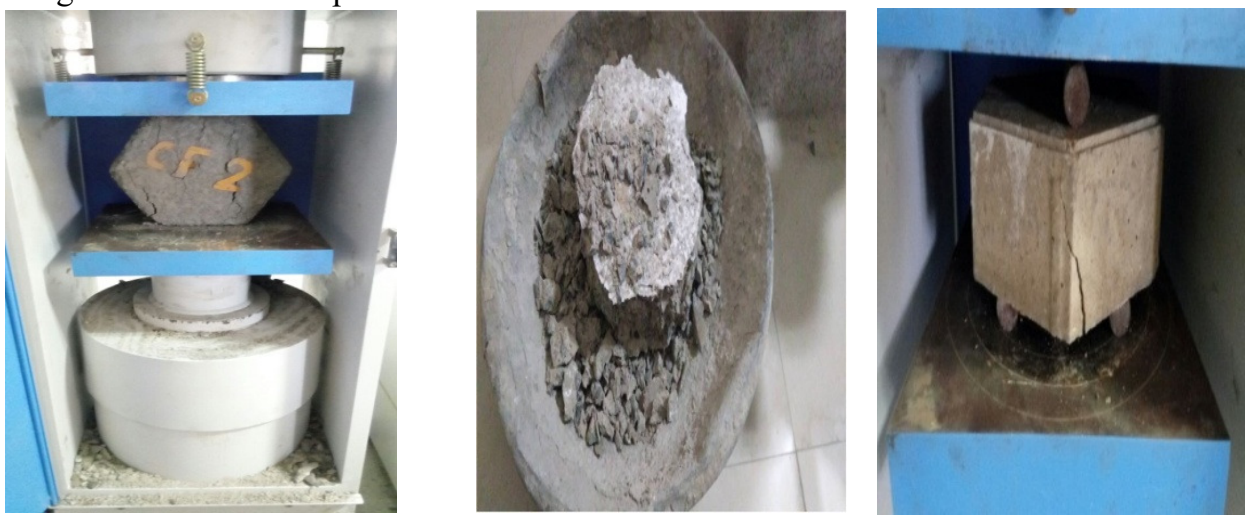

Figure 4 Failure blocks of compressive strength test, Split tensile test, Flexural strength test respectively

4.3 Flexural strength test: As per IS 15658:2006 the load was applied from the top of the specimen in the form of a simple beam loading through a roller of diameter of $25 \mathrm{~mm}$ placed midway between the supporting rollers. The load was applied without shock and increased at an uniform rate of $6 \mathrm{kN} / \mathrm{min}$. (Figure 4) shows the failure block of compressive strength, Split tensile strength, Flexural strength test respectively.

4.4 Water absorption test: The specimen was weighed initially and was completely immersed in water at room temperature for 28 days. Then the specimen was removed from water and dried in room temperature for 24 hours. The dried specimen was weighed and with this noted weights water absorption percentage was calculated. (Figure 5) shows the water absorption test.

4.5 Alkali attack test: Initially weight of the specimen was noted. Alkaline solution is prepared in a container by dissolving $4 \%$ of sodium hydroxide in water. The specimen was completely immersed in alkaline solution and the whole setup was kept in room temperature for 28 days, after which the specimen was removed from the solution and dried in room temperature for 24 hours. The dried specimen was weighed and using this noted weights alkali attack percentage was calculated.

4.6 Acid attack test: Initially the weight of the specimen was noted. Acid solution was prepared in a container by mixing $5 \%$ of concentrated sulphuric acid in water. The test specimen was completely immersed in acid solution and the whole setup was kept in room temperature for 28 days. Then the specimen was removed from the solution and dried in room temperature for 24 hours. The dried specimen was weighed and using this noted weights acid attack percentage was calculated. (Figure 6) shows the alkali attack test, acid attack test. 


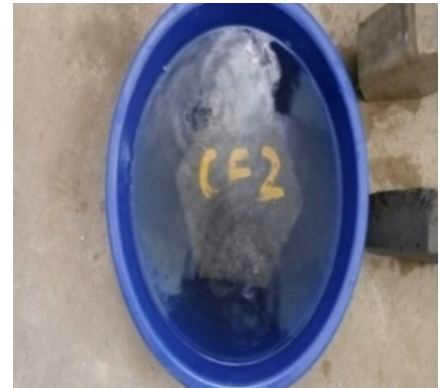

Figure 5 Water absorption test

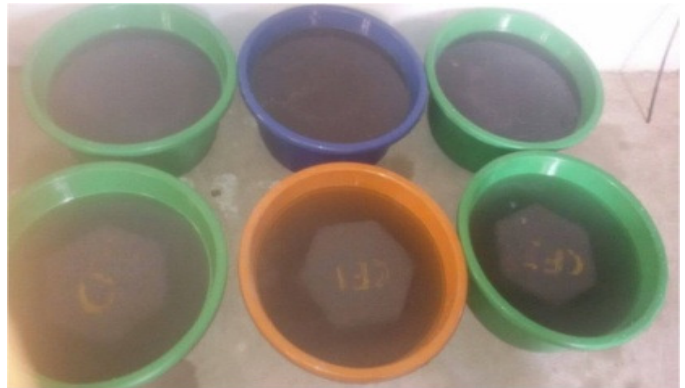

Figure 6 alkali attack and acidattack test

4.7 Abrasion test: Two cubes of $7 \mathrm{~cm} \times 7 \mathrm{~cm} \times 7 \mathrm{~cm}$ were cast in each mix and cured in room temperature for 28 days. The initial dry weight was noted. The weighed, dry specimen was placed on the specimen carrier with the surface to be tested facing the nozzle tip. The nozzle tip was at the middle of the half side of the cube. Then the number of rotations of the cradle was set as 25 and the machine was started. After 25 rotations the sample was removed, cleaned and weighed to determine the loss of mass in grams of the sample. (Figure 7) shows the failure block after abrasion test.

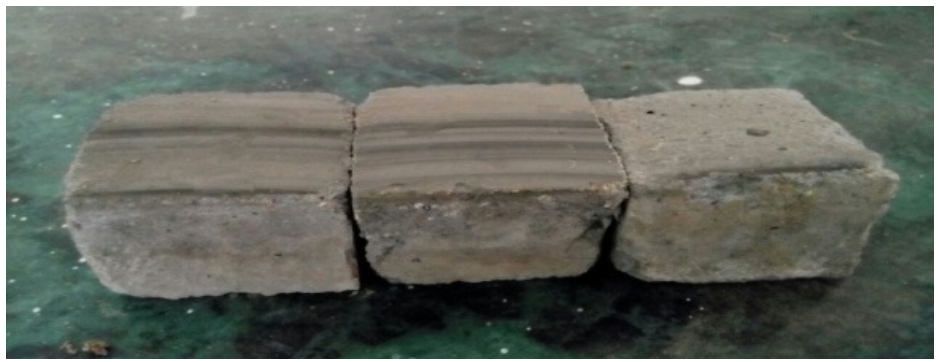

Figure 7 Failure block after Abrasion test

\section{TEST RESULTS}

The results obtained by conducting various experiments are presented here.

5.1Compressive strength, Split tensile strength and Flexural strength

The casted paver blocks have been tested for compression, split tension and flexure. The results of compressive strength test, split tensile strength teat and flexural strength test are tabulated in (Table 4) and represented as bar chart in Figures( 8, 9 \& 10) respectively.

Table 4 Compressive strength, Split tensile strength and Flexural strength in N/mm²

\begin{tabular}{|c|c|c|c|c|c|c|c|c|c|}
\hline \multirow[b]{2}{*}{ Fibre Dosage } & \multicolumn{3}{|c|}{ Compressive Strength } & \multicolumn{3}{|c|}{ Split Tensile Strength } & \multicolumn{3}{|c|}{ Flexural Strength } \\
\hline & $\begin{array}{c}0 \% \\
\text { steel } \\
\text { Fibre }\end{array}$ & $\begin{array}{c}0.25 \% \\
\text { steel } \\
\text { Fibre }\end{array}$ & $\begin{array}{c}0.5 \% \\
\text { steel } \\
\text { Fibre }\end{array}$ & $\begin{array}{c}0 \% \\
\text { steel } \\
\text { Fibre }\end{array}$ & $\begin{array}{c}0.25 \% \\
\text { steel } \\
\text { Fibre }\end{array}$ & $\begin{array}{c}0.5 \% \\
\text { steel } \\
\text { Fibre }\end{array}$ & $\begin{array}{c}0 \% \\
\text { steel } \\
\text { Fibre }\end{array}$ & $\begin{array}{c}0.25 \% \\
\text { steel } \\
\text { Fibre }\end{array}$ & $\begin{array}{c}0.5 \% \\
\text { steel } \\
\text { Fibre }\end{array}$ \\
\hline $\begin{array}{c}\text { Specimen } \\
\text { Designation }\end{array}$ & M-1 & M-2 & M-3 & M-1 & M-2 & M-3 & M-1 & M-2 & M-3 \\
\hline $7^{\text {th }}$ Day & 18.41 & 19.72 & 21.65 & - & - & - & - & - & - \\
\hline $14^{\text {th }}$ Day & 20.08 & 22.15 & 24.61 & 0.40 & 0.54 & 0.74 & 2.63 & 2.92 & 3.03 \\
\hline $28^{\text {th }}$ Day & 21.42 & 23.44 & 26.20 & 0.56 & 0.80 & 0.90 & 3.17 & 3.33 & 3.81 \\
\hline
\end{tabular}

The Compression Strength test for paver block has been carried out. From the above result it is absorbed that compressive strength is maximum when $0.5 \%$ steel fibre is used. This indicates that compressive strength increases with addition of steel fibres. As the maximum compressive strength is $26.20 \mathrm{~N} / \mathrm{mm}^{2}$, this geo-polymer concrete can be used where $\mathrm{M}_{20}$ grade concrete. 


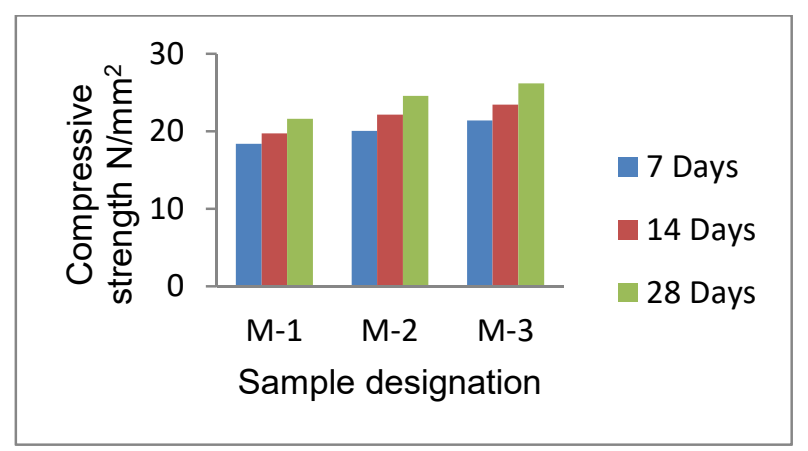

Figure 8 Compressive Strength

The Split Tensile test has been carried out for paver block in shortest length passing through center area. From the above result it is absorbed that the split tensile strength is maximum when $0.5 \%$ steel Fibre is used.This indicates that split tensile strength increases with addition of steel Fibres. From the above result, the maximum split tensile strength obtained is $0.90 \mathrm{~N} / \mathrm{mm}^{2}$.

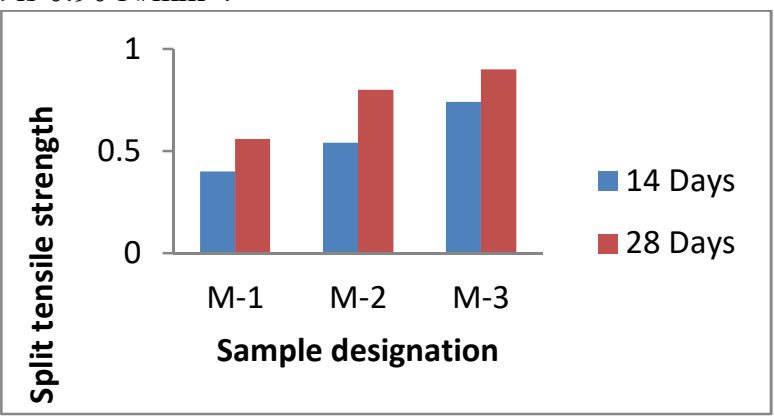

Figure 9 Split tensile Strength

The Flexural strength test for paver block has been carried out. From the above result it is absorbed that the Flexural strength is maximum when $0.5 \%$ steel Fibre is used. This indicates that Flexural strength increases with addition of steel Fibres.From the above result, the maximum Flexural strength obtained is $3.81 \mathrm{~N} / \mathrm{mm}^{2}$.

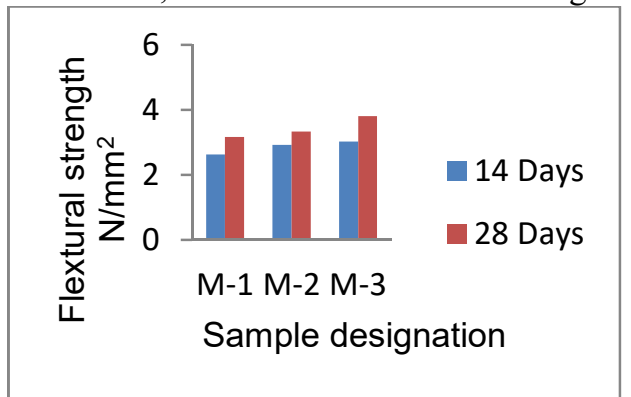

Figure 10 Flexural strength Comparison chart

5.2 Water absorption percentage: The water absorption test for paver block has been carried out and the results are tabulated in Table 5 and represented graphically in (Figure 11). The overall average of water absorption percentage is $=1.29 \%$. As the overall water absorption percentage is less than $10 \%$. This geo-polymer concrete can be used for construction.

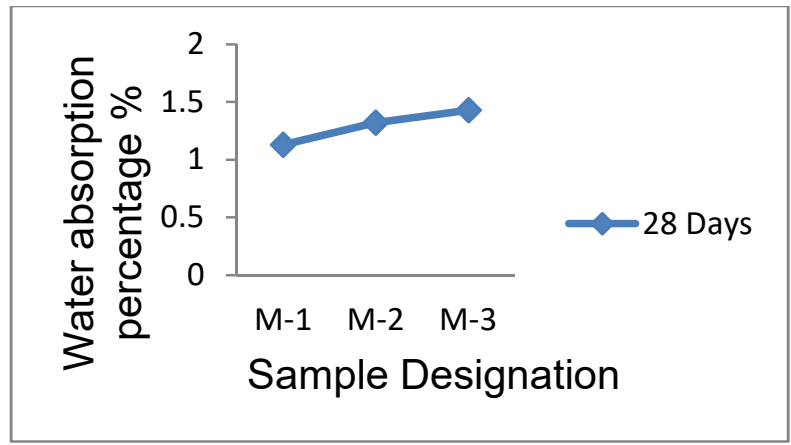

Figure 11 Water absorption 
5.3 Alkali attack percentage: The alkali attack test for paver block has been carried out and the results are tabulated in (Table 5) and represented graphically in (Figure 12). The overall average of alkali attack percentage is $=$ $2.57 \%$.As the overall alkali attack percentage is less than $10 \%$. This geo-polymer concrete can be used for construction

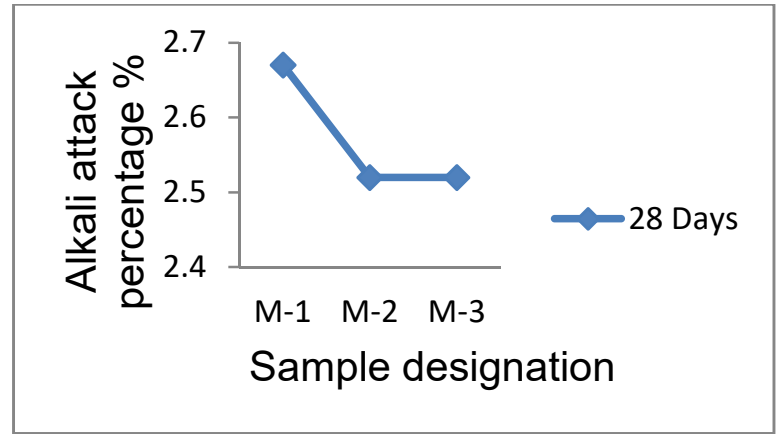

Figure 12 Alkali absorption

Table $5 \%$ of Water absorption, $\%$ of Alkali attack and $\%$ of Acid attack

\begin{tabular}{|c|c|c|c|c|c|c|c|c|c|}
\hline & \multicolumn{2}{|c|}{$\%$ of Water Absorption } & \multicolumn{2}{c|}{$\%$ of Alkali Attack } & \multicolumn{3}{c|}{$\%$ of Acid Attack } \\
\hline Fibre Dosage & $\begin{array}{c}0 \% \\
\text { steel } \\
\text { Fibre }\end{array}$ & $\begin{array}{c}0.25 \% \\
\text { steel } \\
\text { Fibre }\end{array}$ & $\begin{array}{c}0.5 \% \\
\text { steel } \\
\text { Fibre }\end{array}$ & $\begin{array}{c}0 \% \\
\text { steel } \\
\text { Fibre }\end{array}$ & $\begin{array}{c}0.25 \% \\
\text { steel } \\
\text { Fibre }\end{array}$ & $\begin{array}{c}0.5 \% \\
\text { steel } \\
\text { Fibre }\end{array}$ & $\begin{array}{c}0 \% \\
\text { steel } \\
\text { Fibre }\end{array}$ & $\begin{array}{c}0.25 \% \\
\text { steel } \\
\text { Fibre }\end{array}$ & $\begin{array}{c}0.5 \% \\
\text { steel } \\
\text { Fibre }\end{array}$ \\
\hline $\begin{array}{c}\text { Specimen } \\
\text { Designation }\end{array}$ & $\mathrm{M}-1$ & $\mathrm{M}-2$ & $\mathrm{M}-3$ & $\mathrm{M}-1$ & $\mathrm{M}-2$ & $\mathrm{M}-3$ & $\mathrm{M}-1$ & $\mathrm{M}-2$ & $\mathrm{M}-3$ \\
\hline $\begin{array}{c}\text { Initial Weight } \\
\text { (kg) }\end{array}$ & 5.727 & 6.004 & 5.818 & 5.811 & 5.881 & 5.709 & 5.743 & 6.064 & 5.934 \\
\hline $\begin{array}{c}\text { Final Weight } \\
\text { after 28 days } \\
\text { (kg) }\end{array}$ & 5.792 & 6.083 & 5.901 & 5.966 & 6.029 & 5.853 & 5.498 & 5.821 & 5.697 \\
\hline $\begin{array}{c}\text { \% of Water } \\
\text { Absorption }\end{array}$ & 1.13 & 1.32 & 1.43 & 2.67 & 2.52 & 2.52 & 4.27 & 4.01 & 3.99 \\
\hline
\end{tabular}

5.4 Acid attack percentage: The acid attack test for paver block has been carried out and the results are tabulated in (Table 5)and represented graphically in (Figure 13). The overall average of acid attack percentage is $=4.09 \%$. As the overall acid attack percentage is less than $10 \%$ This geo-polymer concrete can be used for construction.

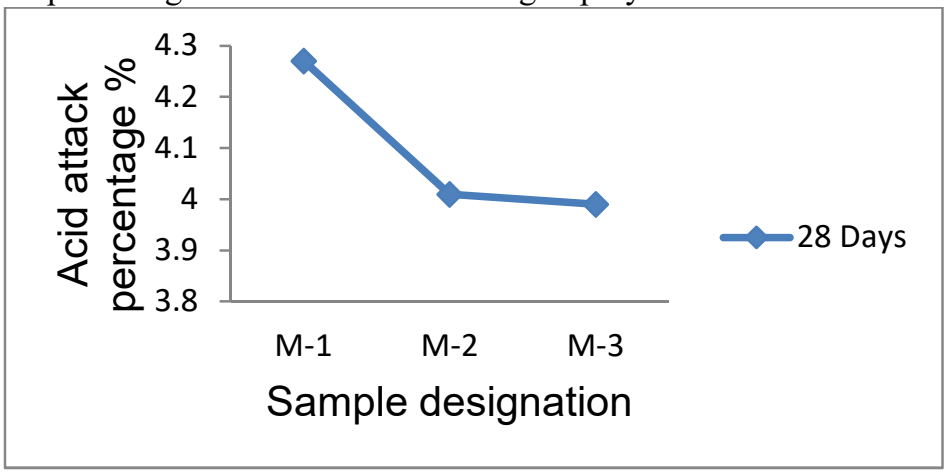

Figure 13 Acid absorption

5.5 Abrasion loss percentage: The abrasion test for cube specimen has been carried out and the results are tabulated in (Table 5) and represented graphically in (Figure 14). The overall average of abrasion loss percentage is $=0.413 \%$. As the overall abrasion loss percentage is less than $10 \%$. This geo-polymer concrete can be used for construction. 


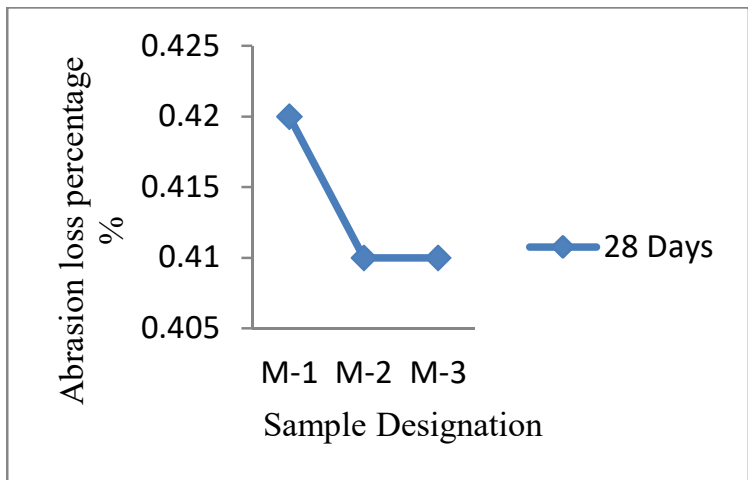

Figure 14 Abrasion loss percentage graph

Table 6 Abrasion loss in percentage

\begin{tabular}{|c|c|c|c|}
\hline Fibre dosage & $0 \%$ steel Fibre & $0.25 \%$ steel Fibre & $0.5 \%$ steel Fibre \\
\hline Sample designation & $\mathrm{M}-1$ & $\mathrm{M}-2$ & $\mathrm{M}-3$ \\
\hline $\begin{array}{c}\text { Initial Weight } \\
\text { Before testing(kg) }\end{array}$ & 0.594 & 0.610 & 0.606 \\
\hline $\begin{array}{c}\text { Final Weight } \\
\text { after testing(kg) }\end{array}$ & 0.592 & 0.608 & 0.604 \\
\hline $\begin{array}{c}\text { \% of } \\
\text { Abrasion loss (\%) }\end{array}$ & 0.42 & 0.41 & 0.41 \\
\hline
\end{tabular}

\section{CONCLUSION}

The addition of steel fibre dosage increases the strength of geo-polymer concrete which is due to the hooked end shape of steel fibre, which provides better adhesion between fibre and concrete.The addition of $0.5 \%$ of steel fibre dosage gave maximum compressive strength of $26.2 \mathrm{~N} / \mathrm{mm}^{2}$. Hence it is concluded that this geo-polymer concrete can be used were M20 grade concrete is used.

Also split tensile and flexural strength results showed maximum values for the same dosage of steel fibre.Since the overall water absorption percentage, alkali attack percentage and acid attack percentage values are less than $10 \%$ it is concluded that this geo-polymer can be used for construction purpose.

Hence, from the results obtained the author concludes that this geo-polymer concrete with steel fibre reinforcement containing Class-' $\mathbf{C}$ ' fly ash can be used for normal construction purpose and thereby we can reduce the carbon-di-oxide $\left(\mathrm{CO}_{2}\right)$ emission during the usage of conventional concrete.

\section{Acknowledgement}

This research was partially supported by International research centre, Sathyabama Institute of science and technology. We thank our colleagues from Sathyabama institute of science and technology who provided insight and expertise that greatly assisted the research and for comments that greatly improved the manuscript.

\section{References}

[1] Ali Nazari, Ali Bagheri, Jay G. Sanjayan, Melissa Dao, Samuel Zumbo,"Thermal shock reactions of Ordinary Portland cement and geopolymer concrete: Microstructural and mechanical investigation" Construction and building materials, Volume 196, 30 January 2019, pp: 492-498.

[2]Anuradha, R. and Sreevidya, V. and Venkatasubramani, R. and Rangan, B. V,"Modified guidelines for geopolymer concrete mix design using Indian standard. Asian Journal of Civil Engineering" (Building and Housing). 13 (3): pp. 353-364.

[3]Cindy K Estakhri, Donald Saylak," Reducing Greenhouse Gas Emissions in Texas with High-Volume Fly Ash Concrete", Vol 1941, Issue 1,2005.

[4]Chamila Gunasekara, David Law, Shamir Bhuiyan, Sujeeva Setunge, Liam Ward,"Chloride induced corrosion in different fly ash based geopolymer concretes" Construction and building materials, Volume 200, 10 March 2019, pp: 502-513.

[5]Grant C. Lukey, Jannie S.J. Van Deventer, John L. Provis and Peter Duxson, "The role of inorganic polymer technology in the development of green concrete", Journal on cement and concrete research, Volume-37, 
Issue-12, pp:1590-1597.

[6] George Mathew,Benny Joseph,'Flexural behaviour of geopolymer concrete beams exposed to elevated temperatures" Journal of building engineeringVolume 15, January 2018, pp: 311-317.

[7] Gaurav Nagalia, Yeonho Park, Ali Abolmaali,Pranesh Aswath," Compressive Strength and Microstructural Properties of Fly Ash-Based Geopolymer Concrete", Vol 28. Issue 12, December 2016.

[8] Mahya Askarian, Zhong Tao, Georgius Adam, Bijan Samali,'Mechanical properties of ambient cured one-part hybrid OPC-geopolymer concrete" Construction and building material, Volume 186, 20 October 2018, pp:330-337.

[9] Peresia Blapoh Wungko, K.Bindumathi," Examining Concrete Properties using Coconut Fiber Ash and Fly Ash as Partial Replacement for cement", Volume 46 Number 5 April 2017

[10] Pratyush Kumar, Chaitanya Pankar, Divyank Manish, Santhi.A.S,'Study of mechanical and microstructural properties of geopolymer concrete with GGBS and Metakaolin"Materials today proceedings, Volume 5, Issue 14, Part 2, 2018, pp: 28127-28135.

[11] K. Pandurangan, M. Thennavan, A. Muthadhi "Studies on Effect of Source of Flyash on the Bond Strength of Geopolymer Concrete" Materials today:proceedings,Volume 5, Issue 5, Part 2, 2018, pp: 12725-12733

[12] Salmabanu Luhar, Sandeep Chaudhary,Ismail Luhar, Thermal resistance of fly ash based rubberized geopolymer concrete" Journal of building Engineering,Volume 19, September 2018, pp: 420-428.

[13] Sudipta Naskar, Arun Kumar Chakraborty,"Effect of nano materials in geopolymer concrete" Perspective in sciencs, Volume 8, September 2016, pp: 273-275.

[14] H Teja Kiran Kumar,K Prasanthi," Experimental study on Coir fibre reinforced flyash based geopolymer concrete with 12M molar activator" Volume 8, Issue 1, January 2017, pp. 438-443,

[15] Visintin.P, Mohamed Ali.M.S, Albitar.M, Luca.W,'Shear behaviour of geopolymer concrete beams without stirrups"Construction and building material, Volume 148, 1 [11], September 2017, pp: 10-21.

[16] Vinh Duy Cao, Shima Pilehvar, Carlos Salas-Bringas, Anna M. Szczotok, Anna-Lena Kjøniksen,” Thermal analysis of geopolymer concrete walls containing microencapsulated phase change materials for building applications" Solar energy,Volume 178, 15 January 2019, pp:295-307. 